\title{
Gender assignment and gender agreement: Evidence from pronominal gender languages
}

\author{
Jenny Audring
}

Received: 18 April 2008/Accepted: 27 March 2009/Published online: 25 April 2009

(C) The Authors(s) 2009. This article is published with open access at Springerlink.com

\begin{abstract}
In research on grammatical gender, assignment and agreement are the two central notions. Genders are defined as systems of agreement classes, and the assignment of nouns to genders is reflected in the agreement they consistently trigger on associated elements. Yet, gender assignment and gender agreement are often discussed quite separately. This paper investigates the possibility that gender agreement is not only an overt manifestation of gender assignment, but that properties of agreement systems can themselves constrain the assignment systems they express. The paper discusses typological and diachronic evidence for the fact that not every type of assignment system can be expressed in every type of agreement system.
\end{abstract}

Keywords Gender · Gender assignment · Gender agreement · Pronominal gender · Typology $\cdot$ Morphology $\cdot$ Agreement $\cdot$ Pronouns

\section{Introduction}

Linguists assume that the gender of nouns is not always learned by rote, but rather that "native speakers have the ability to "work out' the gender of a noun" (Corbett 1991, p. 7). This is done by means of Assignment RULES. Assignment rules can be rules such as the following

(1) (a) Nouns referring to female humans are feminine

(b) Nouns ending in an accented vowel are feminine

(c) Nouns derived by means of the suffix -tion are feminine

J. Audring (ه)

Vrije Universiteit Amsterdam, De Boelelaan 1105, 1081 HV Amsterdam,

The Netherlands

e-mail: j.audring@let.vu.nl 
We can distinguish three types of rule, according to the property on which they are based. (1a) is a semantic gender assignment rule, and very common in the world's languages. (1b) is a phonological gender assignment rule described for Quafar, an East Cushitic language (Corbett 1991, p. 51). (1c), in turn, is a morphological gender assignment rule operating in German.

Gender assignment rules are thought of as having two functions. First, they should alleviate the burden of learning and memorizing the gender of each item in the noun vocabulary of a language. Second, they should enable the speaker of the language to allocate new nouns-loanwords and neologisms-to a gender.

There is a considerable literature on gender assignment, especially for French (e.g. Tucker et al. 1977) and German (e.g. Clyne 1969; Arndt 1970; Lang 1976; Carstensen 1980; Köpcke 1982; Gregor 1983; Schlick 1984; Salmons 1993, 1994; Heringer 1995; Levine 1999), two languages with notoriously complex gender systems. Such studies aim to establish the assignment rules active in a language by means of nonsense word assignments or automated corpus tests in search of semantic and formal properties correlated with a particular gender.

Generally, such studies leave aside gender agreement. This is reasonable, if the markers of covariance between nouns and other elements are seen as no more than the overt manifestation of assignment choices based on the properties of the noun itself. Yet, this approach disregards the importance of agreement as a scaffolding device for the gender-acquiring child, or its function in the adult mind.

By contrast, in descriptive and typological theory, agreement is much more central. Here, gender is understood as a system of AGREEMENT CLASSES (Corbett 1991). That is, the gender of a noun is deduced from the gender marking it consistently triggers on associated elements. Thus, the Swahili noun kiti 'chair' is a class 7 noun, not only because it begins with the prefix $k i$-, but-more importantly-because it causes class-7 agreement to appear on the relevant elements.

(2) Swahili gender agreement

$\begin{array}{lllll}k i \text {-ti } k i \text {-kubwa } c h \text {-a mbao } & k i \text {-po wapi? } \\ \text { 7-chair 7-big } & 7 \text {-PREP wood } & \text { 7-LOC } & \text { where } \\ \text { 'Where is the big wooden chair?' }\end{array}$

Where nominal properties and agreement behaviour suggest different genders, as in the Italian noun la mano 'the hand', the agreements are taken as indicative: despite the word-final /o/, associated with masculine gender, the noun is regarded as feminine.

This paper is an attempt to theoretically link gender assignment and gender agreement in a novel way. Specifically, I want to explore the thought that particular types of gender assignment rules rely on a certain amount of agreement supporting them. The degree to which assignment rules display such a dependency differs in principled ways. With the help of cross-linguistic and historical evidence, I want to propose a systematic correlation between the amount of gender agreement in a language and the organizational principles that underlie its gender system. 


\section{Pronominal gender systems}

One way to find correlations between two factors is to investigate situations in which one of the factors takes extreme values. If, under such circumstances, the other factor shows typical patterns, then there are reasons to assume a dependency relation between the two. For the relation between gender assignment and gender agreement, a relevant extreme situation is represented by pronominal gender systems. These are systems such as we find in present-day English. English has three genders, masculine, feminine and neuter, but these genders are marked exclusively on the personal pronouns. All other agreement targets have lost their gender morphology by attrition. ${ }^{1}$ Thus, the English system can be schematized as in (3).

(3) English gender agreement

\begin{tabular}{|l|l|l|l|}
\hline $\begin{array}{l}\text { Agreeing } \\
\text { element }\end{array}$ & Attribute & Relative pronoun & $\begin{array}{l}\text { Personal } \\
\text { pronoun }\end{array}$ \\
\hline $\begin{array}{l}\text { Example form } \\
\text { and gender }\end{array}$ & the & that/which & $\begin{array}{l}\text { he }[\mathrm{M}] \\
\text { she }[\mathrm{F}] \\
\text { it }[\mathrm{N}]\end{array}$ \\
\hline
\end{tabular}

Languages like English, that mark gender only on the personal pronoun are referred to as pronominal gender languages. They represent an extreme situation because English violates two conditions on canonical agreement (in the sense of Corbett 2005, 2006, 2007).

First, agreement markers usually form sets across word classes. This can be clearly seen in the Swahili example in (2) above. The class 7 agreement appears on a number of elements, the adjective, the preposition and the locative, and more targets could have been added. Thus, there is usually a syntagmatic repetitiveness or redundancy in gender marking. ${ }^{2}$ This redundancy forms the basis for what is often considered the main function of gender: the facilitation of reference tracking and discourse coherence. Pronominal gender systems violate this general rule because only a single agreement target, the pronoun, agrees in gender with the noun. Thus, such systems display a minimum of formal exponence.

Second, in pronominal gender languages, the one agreement target that marks gender is the least canonical of all. Pronouns violate the expectation that agreement targets should share a local domain with their antecedent, preferrably the phrase. Pronouns are not only phrase-external, but even clause-external with regard to their antecedents. In natural speech, they are often separated from their antecedent by large stretches of discourse. Thus, they represent the largest possible agreement

\footnotetext{
1 The distinction between that and which is generally not regarded as a gender distinction, although Quirk et al. (1985, p. 341) advocate such an analysis.

2 Note that repetitiveness or redundancy need not entail formal identity of the markers, as in the alliterative forms of the Swahili example.
} 
domain. Also, there is typological evidence that speakers are sensitive to the difference in syntactic distance among the agreement targets. This fact is captured in the Agreement Hierarchy (Corbett 1979, 2006) which constrains the choices offered by the so-called hybrid nouns. Hybrid nouns are inconsistent agreement controllers. While nouns normally trigger one particular feature value on their agreeing elements, hybrids permit a choice between two or more values. The standard example for English is the noun committee, which many speakers can use with singular and plural agreements on any target but the attributive. Thus, (4a-b) are fine, while (c) is not.

(4) (a) The committee have decided...

(b) The committee decided that they...

(c) *These committee...

Cross-linguistic evidence shows that preferences for one or the other alternative are constrained in principled ways, with attributive elements most strongly favouring syntactic agreement and personal pronouns being most likely to agree semantically. This proves that agreement can be sensitive to target sort, and that pronouns are in some respects an extreme target sort.

These two circumstances - the minimal amount and the non-canonical nature of the agreement markers-make a pronominal gender system a case of maximally poor gender agreement. For our purposes, it is therefore interesting to see which sorts of assignment systems survive on such impoverished formal exponence.

Note that much of the following discussion rests on the assumption that, despite their non-canonical status, pronouns bear an agreement relation with their antecedent (see Barlow 1991, 1992, pp. 134-152; Siewierska 2004, pp. 221-227; Corbett 1991, 2001, 2006 for discussion). One of the many arguments for this view is the fact that mere coreference cannot explain why pronouns mirror the features of their antecedents in languages that do not have a semantics-based gender system. For example, it is difficult to see how the contrast in the two Dutch sentences below can be explained without reference to agreement.

(5) (a) Dit

DEF.SG.N

broer.

brother

(b) Deze

DEF.SG.C

broer.

brother

'This camera is not mine, it's my brother's.' fototoestel is niet van mij, het is van mijn camera( $\mathrm{N})$ is not of me 3sG.N is of my

$\begin{array}{llllll}\text { camera } & \text { is niet van mij, die is van mijn } \\ \text { camera }(c) & \text { is not of me } 3 \text { SG.C is of my }\end{array}$

Semantically, the two sentences are identical, yet the pronoun varies depending on the gender of its antecedent noun. 


\section{Gender assignment in pronominal gender systems}

Purely pronominal gender systems are rare and hard to find, but those that I am aware of show patterns that are informative for the matter at hand. This section looks at the relevant languages by macro-area, while Sect. 4 provides a synthesis of the observed patterns.

The search methodology was random: all pronominal gender languages were taken as found, and all are included in the following.

\subsection{Pronominal gender systems in Indo-European}

Among the Indo-European languages, I am aware of five pronominal gender languages. These are Afrikaans and English (both West-Germanic), Manx, the recently extinct Celtic language formerly spoken on the Isle of Man, Persian and Yazgulyam, both Iranian languages, the latter endangered and spoken in Tadzhikistan. These languages have the following gender assignment systems.

English and Manx both have the familiar system of three genders, commonly called masculine, feminine and neuter. For Manx, there are three pronoun forms. ${ }^{3}$ The form ee (pronounced /i/) is used for female persons and optionally for female animals. The form $y h$ (pronounced /a/) is used for all other referents. In addition, there is the form $e h$ (pronounced /e/) which can be used for males "when the speaker wishes to make the reference clear" (Phillips 2004, p. 18).

The pronouns in the two languages are distributed according to semantic distinctions. There are two splits, one between human and non-human referents and the other between male and female persons. In some cases, there is leakage, such that higher animals are pronominalized by 'human' pronouns. ${ }^{4}$ For Manx, the masculine pronoun is optional: the neuter pronoun can also be used for male humans if there is no emphasis on the sex of the person (John Phillips, personal communication).

Afrikaans has a more difficult pattern. With a similar inventory of pronominal genders it shows wide variation in the use of the masculine and the neuter pronoun.

(6) Afrikaans pronominal genders (third person singular)

\begin{tabular}{|l|l|l|}
\hline \multicolumn{1}{|c|}{ Pronoun } & Nominative & Oblique \\
${ } }$ & & \\
\hline Feminine & hy & hom \\
\hline Neuter & dit & haar \\
\hline
\end{tabular}

\footnotetext{
${ }^{3}$ Manx has very rudimentary gender marking outside the pronominal paradigms: prepositions have forms inflected for gender. They only distinguish two genders: feminine and other. Examples are huggey 'to him/it' vs. huck 'to her' and woish 'from him/it' vs. woee 'from her' (John Phillips, personal communication). This two-gender system is typical for (Insular) Celtic. Manx is exceptional in its use of a specific masculine gender pronoun next to the more general non-feminine pronoun.

${ }^{4}$ For English, the exposition abstracts away from the use of feminine pronouns for ships or cars, which is much discussed in the literature and cannot be given adequate attention here.
} 
Feminine pronouns are used for female persons. For any other referent, a masculine pronoun can be used. Moreover, neuter pronouns appear in reference to animals and inanimate objects (Ponelis 1979; Donaldson 1993, 2000). While Ponelis notes in 1979 that "dit continually retreats from the agressive advance of $h y$ " (1979, p. 585, translation mine), a modern coursebook says that the neuter pronoun dit and the masculine pronouns hy and hom are "just as common" in inanimate reference (Donaldson 2000, p. 13). However, it seems to be the case that the masculine is the preferred choice for concrete and countable objects, while the neuter occurs more often with uncountable and abstract referents (Ponelis 1979, 585 ff; Siemund 2008). Unfortunately, there is little material on modern language usage; especially spoken data would be very interesting.

In general, Afrikaans makes the same splits as English and Manx: one between human and other referents and another between male and female persons. The human-other split is not a sharp cut, rather, the preference for a neuter over a masculine pronoun increases gradually for less individuated referents.

In the Iranian (Pamir) language Yazgulyam, only the oblique forms of the singular pronouns mark gender, and only in the second and the third person. The language has two genders: masculine and feminine (Payne 1989).

(7) Yazgulyam pronominal gender, paradigms

\begin{tabular}{|l|l|l|}
\hline \multirow{2}{*}{ Pronoun } & \multicolumn{2}{|c|}{ Oblique singular } \\
\cline { 2 - 3 } Gender & 2nd person & 3rd person \\
\hline Masculine & day & way \\
\hline Feminine & dim & im \\
\hline
\end{tabular}

Payne describes the use of the pronouns in the following terms. "masc. gender is associated with male humans and inanimate objects, whereas fem. gender is associated with female humans and all animals (regardless of natural gender)" (Payne 1989, p. 429). Thus, Yazgulyam has a semantic system with the oppositions [animal or female human] and [other].

Last but not least, there is Persian, which has lost all traces of the Indo-European gender system except that it has two forms for the third person pronoun: $u$, which translates as 'he' or 'she', and $\bar{a} n$, which means 'it'. The corresponding plural forms are $i s ̌ \bar{a} n$ and $\bar{a} n h \bar{a}$. The distribution of these forms is predictable: $u$ is used for persons (and some higher animals) and $\bar{a} n$ for all other referents. The plural shows the same split into persons and others, with some leakage of person referents into the inanimate domain; Mace (2003, p. 65) notes that $\bar{a} n h \bar{a}$ can refer to persons and/ or things. Unfortunately, the source does not specify if this holds for particular things, and if so, which. Generally speaking, Persian, though regarded as a genderless language, shows a split between common and neuter in the personal pronouns. The distribution of the forms is based on semantics. 


\subsection{Pronominal gender systems in Africa}

Leaving Indo-European, there are a few pronominal gender systems that I am aware of in African languages. From the Niger-Congo family, four languages qualify: Zande, spoken in the Central African Republic, the Democratic Republic of Congo and the Sudan, Defaka, spoken in Nigeria, Klao, a Kru language from Liberia and Jo (or Jowulu), a Mande language from Mali and Burkina Faso. Moreover, Jul'hoan, a Khoisan language spoken in Angola, Botswana and Namibia, is a candidate. We'll briefly look at each language in turn.

Zande has four genders, expressed on personal pronouns (although gender marking is spreading to other sentence elements). Table (8) gives the paradigm (from Claudi 1985, p. 90, alternative forms indicate different descriptions by different grammars).

(8) Zande, third person pronouns, paradigms

\begin{tabular}{|c|c|c|c|c|}
\hline Pronoun & \multicolumn{2}{|c|}{ Singular } & \multicolumn{2}{|c|}{ Plural } \\
\hline & Subject & Object & Subject & Object \\
\hline Masculine & ko, kù & ko & \multirow{2}{*}{$i, y o$} & \multirow[b]{2}{*}{ yo } \\
\hline Feminine & $r i, l i$ & ri,li & & \\
\hline Animate & $u$ & $r u, l u$ & ami & $\mathrm{ra}$ \\
\hline Neuter & $s i, t i$ & $e, h e, n i$ & $s i, t i$ & $e, n i, h e, h a$ \\
\hline
\end{tabular}

The gender distinction is extended into the plural paradigm, although here the masculine and the feminine are merged.

The pattern of distribution is semantic, with a masculine gender for male persons, a feminine gender for female persons, an animate gender for animals and a fourth gender for all other referents. There is occasional leakage: for small children, the animate pronoun is used, and some inanimates also take the animate pronoun. Zande thus makes a triple split, one between animates and inanimates, one between persons and other animates and a sex-based split among the human animates, the latter only in the singular.

Defaka (also known as Afakani) is an Ijoid language with a three-gender system that is exceptional in its genetic area, the South-Central branch of Niger-Congo. Together with its close relative, Ijo, it is the only language of this group that has a sex-based gender system. ${ }^{5}$ The pronominal forms are given under (9).

\footnotetext{
${ }^{5}$ Ijo itself is another candidate for a pronominal gender system, but its only well-documented dialect has "a system of definite articles suffixed to the noun, apparently developed from demonstratives" and among them "[a] separate feminine [...] demonstrative and definite article" (Williamson 1965, p. 6). Thus, it has developed attributive gender marking and does no longer qualify for the type of language investigated here.
} 
(9) Defaka third person singular pronouns (from Jenewari 1983, p. 103)

\begin{tabular}{|l|c|}
\hline Gender & $\begin{array}{c}\text { Third person } \\
\text { singular }\end{array}$ \\
\hline Masculine & $o$ \\
\hline Feminine & $a ́$ \\
\hline Neuter & $y e$ \\
\hline
\end{tabular}

Despite its unusualness in this group of languages, the system is very common in terms of gender assignment: it shows the same organization as English and Manx. The pronouns $o$ and $a$ are used for male and female humans respectively, while ye refers to all other referents.

In the Mande branch of Niger-Congo, which is otherwise genderless, we find the language Jo, described by Carlson 1993 who explicitly compares it with Defaka. This language has a gender system that is similar to English.

(10) Jo personal pronouns, paradigms

\begin{tabular}{|l|c|c|}
\hline \multicolumn{1}{|c|}{ Pronoun } & Singular & Plural \\
Gender & & \\
\hline Masculine & $\dot{u}$ & \multirow{2}{*}{$k i ́$} \\
\hline Feminine & $n i$ & \\
\hline Neuter & $\grave{j}$ & yìrì \\
\hline
\end{tabular}

The three singular pronouns are distributed according to natural gender, with a tripartite split into male, female and other. The plural pronouns collapse the male/ female distinction and distinguish human and other referents.

Klao, described as "Kru" by Rickard 1970, the fourth Niger-Congo language with a pronominal gender system, has an intriguing pronominal paradigm which codes not only gender and number but also verbal aspect (completive/incompletive). Gender is only distinguished in the third person singular. There are two forms, 0 , translated as 'he/she' and $e$ or $\varepsilon$ (the former variant is given in Rickard 1970, the latter in Marchese 1988, p. 330), translated as 'it'. The forms are reduplicated in incompletive aspect, and they are identical for subject and object (first and second person pronouns do distinguish case). Unfortunately, the grammar does not explicitly give the distribution of the forms, but according to Marchese (1988, p. 330), the distinction is between human and non-human.

Williamson and Blench (2000) further mention a feminine in the second and third person singular pronoun in the Kru languages Niaboua (also known as Nyambwa) and Wobé (also known as Wè). Since the Kru languages are not typical gender languages, these genders might be purely pronominal; unfortunately, no grammars were available. 
Another candidate among the African languages is the Khoisan language Jul'hoan, as described by Dickens 2005 and discussed in Güldemann 2000. Güldemann explicitly analyzes it as a pronominal gender language (Güldemann 2000 , p. 7). This language has five genders, distinguished in the pronominal paradigms. Syncretism is pervasive, only gender $\mathrm{V}$ has unique forms across the different pronoun types, and gender II is non-autonomous (term from Baerman et al. (2005, p. 15) following Zaliznjak 1973 [2002]). This means that gender II does not have any morphological forms that are unique to this gender and do not also occur in other genders. Table (11) gives the paradigms.

(11) Jul'hoan pronominal genders (after Güldemann 2000)

\begin{tabular}{|c|c|c|c|c|c|c|}
\hline \multirow{2}{*}{ Gender } & \multicolumn{3}{|c|}{ Free pronoun } & \multicolumn{2}{|c|}{ Pronoun as possessum } & \multirow{2}{*}{$\begin{array}{l}\text { Proximal } \\
\text { demonstrative }\end{array}$} \\
\hline & $\mathrm{Sg}$ & $\mathrm{Du}$ & $\mathrm{Pl}$ & $\mathrm{Sg}$ & $\mathrm{Pl}$ & \\
\hline $\mathrm{I}$ & $h a$ & sá & sì & $m a ̀ ~$ & $h \grave{i}-s \grave{i}$ & hè \\
\hline II & $h a$ & - & $h \grave{i}$ & 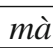 & $h \grave{i}-s \grave{i}$ & hè \\
\hline III & $h a$ & - & ha & $m \grave{a}$ & $m \grave{a}-s \grave{i}$ & hè \\
\hline IV & hì & - & hì & hì & $h \grave{\imath}-s \grave{\imath}$ & $h \grave{e}$ \\
\hline $\mathrm{V}$ & ká & - & ká & $g a ́$ & gàsì & $k \grave{e}$ \\
\hline
\end{tabular}

According to Güldemann, pronouns are distributed according to semantic or to formal considerations. On the basis of field data by Dickens (published later as Dickens 2005), Güldemann (2000) lists the following semantic classes.

gender I: humans

gender II: animals, other nationalities

gender III: plants, plant food

gender IV: long objects

gender V: body parts, 'thing, matter', verbal nouns

However, Dickens (2005, p. 31) himself notes that the semantic classes are "general guide-lines" rather than accurate predictors, and there are numerous exceptions.

In my view, there is reason to doubt the status of the language as a purely pronominal gender language, i.e. as a language where gender marking is restricted to pronominal targets. Both the possessive pronouns and the free personal pronouns can be used attributively. Dickens (2005, p. 63) gives two examples:
(12) ha
dshàú
PRO.SG.I
woman
'that (previously mentioned) woman'
$\begin{array}{ll}\text { ká } & \text { !aíhn } \\ \text { PRO.SG.V } & \text { tree }\end{array}$
'that (previously mentioned) tree' 
In general, Jul'hoan has an "unusual system" (Baerman et al. 2005, p. 90), and the available grammar sketch does not answer all the questions.

\subsection{Pronominal gender systems in the Americas}

Moving on to the Americas, we find pronominal gender systems among the Amazonian languages. Candidates are the Mura language Pirahã, a number of Cariban languages, Parintintín and Kayabí from the Tupí-Guaraní genus, and possibly four or five of the Macro-Ge languages. Beyond the Amazon, there is the Oto-Manguean language Mixtec (Chalcatongo variety) which possibly has a relevant sort of gender system. Two other cases are Southeastern and Eastern Pomo. We will look at the gender assignment systems briefly.

Pirahã has three bound pronouns which can be regarded as marking gender (their free form counterpart has a single form only and thus cannot mark agreement). These forms are $x i$, xís and $h i$ (Everett 1986) and their distribution can be schematized as follows. The feminine pronoun $x i$ refers to female persons and the masculine pronoun xís is used for male humans and all animals, leaving the neuter $h i$ as a residue category for inanimate referents. This system resembles many other systems of pronoun distibution we have seen, but it is unique in this particular patterning of semantic classes and genders.

Among the Cariban languages, there are several pronominal gender languages. We will only look at Hixkaryana, a language spoken in Brasil. In this language, the third-person pronouns have deictic variants with a three-way division in proximal, medial and distal, and the gender split pervades through all the third-person forms.

(13) Hixkaryana third person singular pronouns (after Derbyshire 1979, p. 127)

\begin{tabular}{|l|l|l|}
\hline Pronoun & gender I & gender II \\
\hline Non-deictic & noro & tro \\
\hline Proximal & mosoni & oni \\
\hline Medial & mokro & moro \\
\hline Distal & moki & moni \\
\hline
\end{tabular}

The pronouns, as in all the relevant Cariban languages, are distributed according to a simple semantic pattern: the gender I set is used for animates, the gender II set for inanimates. The other related languages are Carib, De'kwana, Panare, Tiriyo, WaiWai and Wayana (Derbyshire 1990, p. 54).

Tupí-Guaraní is a language group that generally lacks gender as a morphosyntactic feature, but individual languages may display gender distinctions in the paradigms of the personal pronouns. For example, the languages Parintintín and Kayabí each have three bound third-person forms (Jensen 1999). 
(14) Pronominal gender in Parintintín and Kayabí

\begin{tabular}{|c|c|c|}
\hline Gender $\quad$ Language & Parintintín & Kayabí \\
\hline masculine & $g a$ & ina \\
\hline feminine & $h \tilde{e}$ & $\tilde{e} \tilde{e}$ \\
\hline neuter & $i-/ t-/ t s{ }^{6}$ & $i-/ t-/ t s-$ \\
\hline
\end{tabular}

The distribution of these pronominal forms is sex-based, as in English and many other languages. Thus, we see the familiar split of [male], [female] and [other].

The same split can also be observed a number of Macro-Ge languages. Wiesemann (1986) mentions pronominal gender in the third-person pronoun paradigms of Kaingáng, Xokléng and Rikbaktsá. Besides, she notes a human/non-human distinction in the third person pronouns of Xerenté and Kayapó, which-contrary to her analysis-could be analyzed as genders. Unfortunately, no information is available on the presence or absence of gender marking in the rest of the grammar of these languages, so the issue is open until more material is on hand.

Outside the Amazon, a potentially interesting language is Chalcatongo Mixtec, spoken in Mexico and described in Macaulay 1996. This language has a number of third-person pronouns that still bear clear traces of their origins as nominal classifiers: they are formally identical to nouns meaning 'man', 'woman', 'animal' and so on. The gender system is not fully formed: the (clitic) pronouns are optional and there is no form for inanimate referents. Besides, there is interaction with a honorifics system. As with all classifier systems, the classes are semantically organized. Since the forms are not clearly a case of gender agreement, they should not be considered as evidence.

Finally, pronominal gender systems can be found in Eastern and Southeastern Pomo (there seem to be no gender distinctions in Central Pomo, see Mithun 1990). In both varieties, there are two gender-specific suffixes that only occur with personal pronouns of the third person (in Eastern Pomo, an exception are the nouns qawéli-p/ qawéli-t 'second or third persons grandson/granddaughter' that also bear this marker, McLendon 1975, pp. 164-165). In Eastern Pomo, the third person pronouns are $m i-p$ for masculine and mí- $t$ for feminine antecedents (McLendon 1975, p. 107). The paradigm for Southeastern Pomo is given in (15) (data from Moshinsky 1974). The grammar mentions a distinction between displaced and non-displaced referents, meaning "the presence or absence of the referent of the demonstrative in the speech situation. It could alternatively be termed 'visibility', since presence in the visual field is also part of the distinction" (Moshinsky 1974, p. 99). The category nondisplaced has a three-way split according to deictic proximity.

\footnotetext{
${ }^{6}$ The three neuter affixes are distributed according to stem class (Jensen 1999, p. 148).
} 
(15) Southeastern Pomo third person singular personal pronoun, subject forms

\begin{tabular}{|l|l|l|}
\hline Pronoun & Masculine & Feminine \\
\hline Near & míyi & mémed \\
\hline Unmarked position & 2́yi & ?ómed \\
\hline Far & ¿yi & [form not mentioned in grammar] \\
\hline Displaced & yíwi & yímed \\
\hline
\end{tabular}

Unfortunately, the sources do not disclose the exact distribution of the gendermarked pronouns. There is clearly some correlation with the natural gender of the (animate) referent, but it is unclear if anaphoric pronouns can refer to inanimate referents and what form is used in that case. There are no other gender distinctions elsewhere in Eastern and Southeastern Pomo, making the system entirely pronominal.

\subsection{Pronominal gender systems in Asia, Australia, New-Guinea}

For the rest of the world, I am aware of seven pronominal gender languages, though the list is certainly not exhaustive. In Australia, I have found three relevant cases, two of them from different genetic groups. The first is the nearly extinct language Diyari, a Pama-Nyungan language, which has two pronominal genders. The assignment system reveals a pattern that Corbett (1991, p. 11) calls "noteworthy": one pronoun is used for female persons, the other for all other referents. Table (16) shows that the distinction pervades through all case variants of the third person singular personal pronoun (data from Austin 1981). ${ }^{7}$

(16) Diyari third person singular pronouns, paradigm

\begin{tabular}{|c|c|c|c|c|c|c|}
\hline $\begin{array}{l}\text { Case } \\
\text { Gender }\end{array}$ & Ergative & Nominative & Accusative & Dative & $\begin{array}{l}\text { Locative/ } \\
\text { Allative }\end{array}$ & Ablative \\
\hline Feminine & nandu & nani & nana & nankaṇi & nankanu & nankanundu \\
\hline $\begin{array}{l}\text { Non- } \\
\text { feminine }\end{array}$ & nulu & nawu & nina & nunkaṇi & nuпkaпu & nupkayundu \\
\hline
\end{tabular}

A very similar pattern is found in the related language Pitta Pitta (Blake 1979, pp. 193-194). This language has the masculine prefix n $u$ and the feminine prefix na which occur on personal pronouns throughout the three cases and the three levels of deictic proximity (near, general, far). This seems to be the only morphosyntactic exponence of gender. In Pitta Pitta, the feminine forms are used for female persons and animals, the masculine forms for all other referents. Austin (1981, p. 60)

\footnotetext{
7 Note that the Diyari pronouns can also be used as determiners inside the noun phrase, so the gender system is not (or no longer) entirely pronominal. 
mentions similar gender-distinguishing pronominal bases in the related languages Yandruwandha, Ngamini and Yarluyandi.

Interestingly, the same pattern returns in the unrelated Sepik-Ramu language Awtuw from Papua New-Guinea. This language has two free third-person pronouns: tey (feminine) and rey (masculine) (Feldman 1986 and personal communication). As in Diyari, the feminine pronoun refers to female persons, while the masculine pronoun can occur with any other referent.

Moving on to the next macro-area, Austro-Asiatic, we find the same genderassignment pattern returning in the Mon-Khmer language Khmu, spoken in Laos.

(17) Khmu pronominal genders (Premsrirat 1987, p. 33)

\begin{tabular}{|l|c|c|}
\hline \multirow{2}{*}{ Pronoun } & \multicolumn{2}{|c|}{ Singular } \\
\cline { 2 - 3 } Gender & second person & third person \\
\hline Masculine & $j \grave{\varepsilon}^{?}$ & $k \grave{s}$ \\
\hline Feminine & $p \grave{a}:$ & $n \grave{a}:$ \\
\hline
\end{tabular}

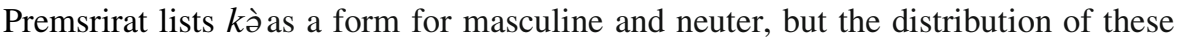
forms shows that the analysis in terms of a third gender is entirely based on semantic considerations, not on morphology: "masculine and feminine natural gender for humans contrast for the second and third person singular pronoun. The third person pronoun for an inanimate referent has the same form of pronoun as that of the masculine" (Premsrirat 1987, p. 32). Thus, Khmu resembles Diyari, Pitta Pitta and Awtuw in that it has a two-gender system employing the semantic parameters [female human] and [other].

Moreover, there is a pronominal gender language in the Sino-Tibetan family: both the Classical and the Lhasa variant of Tibetan have two personal pronouns, kho 'he' and mo 'she', which are used for male and female persons, respectively. Otherwise, the distal demonstrative de 'that' is used (DeLancey 2003a and b, thanks to Seth Cable for alerting me to these facts). The two forms kho and mo occasionally appear on nouns and adjectives and seem to be a remnant of an earlier agreement system that is now lost (DeLancey 2003b, p. 276) and is only retained in the personal pronouns. In terms of distribution, Tibetan resembles English with a three-way split into male, female and other referents.

We conclude our world tour of pronominal gender languages with the Dravidian language Malayalam. From the description by Asher and Kumari 1997, it is clear that gender agreement is practically restricted to pronouns. "The justification of noun classes [...] depends neither on morphological features [...], nor on features of concord within a noun phrase. Nor is concord with verbs relevant [...]. Gender does determine some aspects of grammar, however, and these have to do with a sort of concord. Firstly, the choice of pronoun among avan, aval and ato is determined by 
whether a noun is masculine, feminine or neuter." (Asher and Kumari 1997, p. 252). ${ }^{8}$ Thus, the Malayalam personal pronouns agree in gender. The three forms are distributed according to semantic criteria. "Masculine nouns denote male human beings, feminine nouns denote female human beings, and neuter nouns nonhumans. Gods and demons are grouped with humans. Infants fall into the neuter class" (Asher and Kumari 1997, p. 252). In the plural, masculine and feminine are merged into a human class. Schema (18) gives the paradigm.

(18) Malayalam third person pronouns, paradigm

\begin{tabular}{|l|l|l|}
\hline \multicolumn{1}{|c|}{ Pronoun } & Singular & Plural \\
Gender & & \\
\hline Masculine & avan & \multirow{2}{*}{ avar } \\
\hline Feminine & aval & \\
\hline Neuter & atə & ava \\
\hline
\end{tabular}

The distibution of the singular pronouns is roughly as in English, Manx and Jo.

After this sketch of pronominal gender languages, it is time to return to the original question, which is whether there are commonalities among those languages with pronominal gender agreement. In particular, we wanted to know whether poor gender agreement coincides with particular gender assignment rules, in order to gain a better understanding of the relation between the organizational principles that underlie gender systems and their formal exponence in the morphology.

\section{Synthesis}

If this survey is representative, there are clear patterns in the assignment systems of pronominal gender languages.

The first generalization is that pronominal gender systems have a small range of genders. The largest system found is that of Zande, with four genders. However, of the 112 gender languages listed in the World Atlas of Language Structures (WALS, Haspelmath et al. 2008), 88 languages have systems with two to four genders. If larger systems are much less common anyway, the generalization is weak for the small group of pronominal gender languages.

A more significant generalization is that all pronominal gender systems are semantically organized. This is not the general typological pattern: more than half of the 112 gender languages in the WALS sample have partly form-based gender

\footnotetext{
8 Asher and Kumari further note that "predicative 'adjectives' (which in terms of their morphology are usually nominal in structure) must often match the subject noun in this respect" (ibid.). In my view, the latter structures do not represent an instance of agreement, as the denominal adjectives all bear the same adjectival suffix, with the gender-specificity being part of a the meaning of the base noun. This seems to be comparable to forms such as womanly in English, which carry gender-related meaning but are not regarded as gender-marked.
} 
assignment. Among the pronominal gender languages, only the problematic candidate Jul'hoan has an assignment system that is not purely semantic.

Third, the assignment systems are similar in that they all make use of common, basic distinctions such as male/female, human/non-human, animate/inanimate and count/mass. These property pairs figure largely in typological research, and many grammatical distinctions are sensitive to them. Again, Jul'hoan is the one language that illustrates the alternative: a gender system with more specific semantic classes such as long objects or body parts. Among the languages with richer agreements or agreement closer to the noun, there are many more of this type: Dyirbal famously has semantic classes for dangerous things (gender II) and non-flesh food (gender III) (Dixon 1972), ${ }^{9}$ German pairs feminine gender with exotic fruit (Köpcke and Zubin 1984 and elsewhere), and in Norwegian, nouns referring to dairy products are masculine (Enger 2006). Such comparably small classes are not generally found in pronominal gender languages.

A fourth generalization is that the pronominal gender languages employ the relevant semantic distinctions in such a way that the distribution of the pronouns can be aligned to a conceptual scale. A useful version of such a scale is the Individuation Hierarchy (after Sasse 1993, p. 659), a variant of the Animacy Hierarchy. This hierarchy sorts referents according to decreasing individuation, from sex-differentiated humans as the most individuated class to uncountable and abstract nouns as the least individuated.

\section{Individuation Hierarchy}

$\begin{aligned} & \text { male } \\ & \text { human } \\ & \text { female } \\ & \text { human }\end{aligned}>$ animal $>\begin{aligned} & \text { inanimate } \\ & \text { object }\end{aligned}>\begin{aligned} & \text { mass } / \\ & \text { abstract }\end{aligned}$

In almost all the languages presented, the pronominal genders are aligned to the hierarchy in such a way that each pronoun is associated with a single uninterrupted domain. The only difference between languages are the cut-off points between one gender and the next. Table (20) illustrates the situation.

\footnotetext{
9 In Dyirbal, the agreeing elements are "analogous to demonstratives" and can also be used as free pronouns (Corbett 1991, p. 106), but as they also occur attributively to the noun, this does not make Dyirbal a pronominal gender language.
} 
Table (20) The Individuation Hierarchy and the pronominal genders ${ }^{10}$

\begin{tabular}{|c|c|c|c|c|c|c|c|}
\hline Hierarchy & $\begin{array}{l}\text { male } \\
\text { human } \\
\text { female } \\
\text { human }\end{array}$ & $>$ & animal & $>$ & $\begin{array}{l}\text { inanimate } \\
\text { object }\end{array}$ & $>$ & $\begin{array}{l}\text { mass/ } \\
\text { abstract }\end{array}$ \\
\hline \multirow{2}{*}{$\begin{array}{l}\text { English, Defaka, Jっ } \\
\text { (singular), Parintintín, } \\
\text { Kayabí, Tibetan, } \\
\text { Malayalam (singular) }\end{array}$} & - & & \multirow{2}{*}{$\Delta$} & \multirow{2}{*}{\multicolumn{2}{|c|}{$\Delta$}} & \multirow{2}{*}{\multicolumn{2}{|c|}{$\boldsymbol{\Delta}$}} \\
\hline & $\square$ & & & & & & \\
\hline \multirow{2}{*}{ Manx } & $\boldsymbol{a} / \boldsymbol{\Delta}$ & & \multirow{2}{*}{$\boldsymbol{\Delta}$} & \multirow{2}{*}{\multicolumn{2}{|c|}{$\mathbf{\Delta}$}} & \multirow{2}{*}{\multicolumn{2}{|c|}{$\Delta$}} \\
\hline & $\square$ & & & & & & \\
\hline \multirow{2}{*}{ Afrikaans } & - & & \multirow{2}{*}{$\boldsymbol{a} / \mathbf{\Delta}$} & \multirow{2}{*}{\multicolumn{2}{|c|}{$\boldsymbol{\nabla} / \boldsymbol{\Delta}$}} & \multirow{2}{*}{\multicolumn{2}{|c|}{$\boldsymbol{\square} / \boldsymbol{\Delta}$}} \\
\hline & $\square$ & & & & & & \\
\hline \multirow{2}{*}{ Yazgulyam } & - & & \multirow{2}{*}{$\square$} & \multirow{2}{*}{\multicolumn{2}{|c|}{ घ }} & \multirow{2}{*}{\multicolumn{2}{|c|}{ घ }} \\
\hline & $\square$ & & & & & & \\
\hline \multirow{2}{*}{ Zande (singular) } & - & & \multirow{2}{*}{$\boldsymbol{\Delta}$} & \multirow{2}{*}{\multicolumn{2}{|c|}{0}} & \multirow{2}{*}{\multicolumn{2}{|c|}{0}} \\
\hline & $\square$ & & & & & & \\
\hline \multirow{2}{*}{$\begin{array}{l}\text { Persian, Jo (plural), } \\
\text { Klao, Malayalam (plural) }\end{array}$} & $\square$ & & \multirow[t]{2}{*}{ घ } & \multirow{2}{*}{\multicolumn{2}{|c|}{ - }} & \multirow{2}{*}{\multicolumn{2}{|c|}{ a }} \\
\hline & $\square$ & & & & & & \\
\hline \multirow{2}{*}{ Pirahã } & $\square$ & & \multirow{2}{*}{ - } & \multirow{2}{*}{\multicolumn{2}{|c|}{$\boldsymbol{\Delta}$}} & \multirow{2}{*}{\multicolumn{2}{|c|}{$\mathbf{\Delta}$}} \\
\hline & $\square$ & & & & & & \\
\hline \multirow{2}{*}{ Hixkaryana } & $\square$ & & \multirow{2}{*}{$\square$} & \multirow{2}{*}{\multicolumn{2}{|c|}{ घ }} & \multirow{2}{*}{\multicolumn{2}{|c|}{ घ }} \\
\hline & $\square$ & & & & & & \\
\hline \multirow{2}{*}{$\begin{array}{l}\text { Diyari, Pitta Pitta, } \\
\text { Awtuw, Khmu }\end{array}$} & - & & \multirow[b]{2}{*}{ घ } & \multirow{2}{*}{\multicolumn{2}{|c|}{ घ }} & & \\
\hline & $\square$ & & & & & & - \\
\hline Zande (nlural) & $\square$ & & - & & A & & A \\
\hline & $\square$ & & 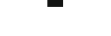 & & 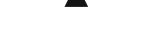 & & \\
\hline
\end{tabular}

Besides, again, Jul'hoan, there is a single exception to this principle of connectivity (Haspelmath 1997, 2004; Croft 2001), i.e. to the general pattern that each pronoun is aligned with one particular area on the scale. Yazgulyam has a masculine gender that is used for male persons and inanimate objects. Its distributional field is interrupted by the feminine gender pronoun that is used not only for female persons, but also for all animals.

The Khoi-San language Jul'hoan, whose status as a pronominal gender language is contestable, violates all four generalizations. It has five genders and it is only partly semantically organized. It employs semantic rules that are cognitively less basic than those of the other systems, and these cannot be usefully aligned to a conceptual scale. In this light, more data of this language would be most desirable.

Coming back to the original question, the data suggest a link between the type of agreement system and the type of assignment system in the languages of the world.

\footnotetext{
${ }^{10}$ The same symbols represent the same gender (within an individual language). When the distributions differ for singular and plural pronouns in a particular language, both variants are given. A slash indicates variation or choice between two genders.
} 
If, as argued at the outset of this paper, pronouns represent an extreme case of impoverished gender agreement, then poor agreement correlates with semantic assignment based on simple, basic conceptual distinctions. Interestingly, this hypothesis finds support in other facts and circumstances in gender systems.

\section{Additional evidence}

\subsection{Diachrony}

One type of evidence for a correlation between purely pronominal gender agreement and semantic assignment can be found in the historical development of the English language from Old-English to Modern English.

Old English had a gender system much like that of Present Day German. Nouns belonged to masculine, feminine or neuter gender, as reflected in a number of agreement targets, among others the articles and the adjective. Gender assignment was of the mixed type consisting of formal and semantic rules. Semantic rules basically applied to nouns referring to persons and were sex-based (with wellknown exceptions such as wif $[\mathrm{N}]$ 'woman'). Formal rules are connected to inflectional classes. For example, $u$-stem nouns such as duru [F] 'door' were non-neuter.

Already in Old English, pronouns could defy this system. Thus, we find cases of syntactic agreement side by side with semantic agreement, as in (21).

\section{(21) Old English}

... pæt pu pone wisdom be be God sealde,

that you that wisdom which to.you God gave

pær pær pu hiene befæstan mæge, befæste.

there where you PRO.SG.M implant may implant

Gepenc hwelc witu us pa becomon

think what punishments to.us then came

for pisse worulde, pa pa we hit nohwæer

for this world(F) when we PRO.SG.N neither

ne selfe ne lufodon, ne eac oprum

not ourselves not loved not as other

monnum ne lefdon ...

men not allowd 
'... that wisdom which God gave to you, where you may implant it, there implant it. Think what punishments would come to us for this world if we did not love it nor allowed others to do so ...' (Preface to the Cura Pastoralis, quoted from Dekeyser 1980, p. 101)

The relative distribution of syntactic and semantic agreement in Old English pronoun usage is contended in the literature. Older studies, e.g. Moore 1921, claim that the use of the gender-distinctive pronouns in Old English "was almost the same as our own use of them" (89). Yet, there is a danger that these studies overrate the use of pronouns for person reference, which constitutes the bulk of the pronouns in the corpora. For the pronouns referring to inanimate nouns, Curzan (2003) reports "robust health" (91) of the traditional system of grammatical gender agreement until the Early Middle English period.

Thus, the distribution of the pronouns in inanimate reference is most interesting to our purposes. After the Old English period, speakers ceased to use masculine or feminine pronouns for inanimates (with some well-known exceptions such as ships and cars, although it is questionable to what extent this usage reflects lexical/grammatical rather than semantic agreement). This development coincided with the loss of the nominal and adnominal gender exponents. Apparently, the reduction of the agreements to the pronominal domain had consequences for the distribution of the pronominal genders. It is important to realize that such a causal connection between the loss of agreement morphology and the restructuring of the assignment system is not self-evident. After all, "the historical gender system as it operated in Old English could be preserved here [i.e., on the pronouns]" (Dekeyser 1980, p. 100). Yet, this is not what happened. With the loss of agreement morphology, the nominal genders lost their footing and the pronouns were redistributed. The redistribution occurred on the basis of semantic rather than lexico-syntactic properties. This correlation supports the hypothesis that there is indeed an intimate relationship between the (low amount of) gender agreement in pronominal gender systems and (semantic) gender assignment. The diachronic data from English point toward the same conclusion as the crosslinguistic syncronic data presented in the previous sections.

\subsection{Evidence from partly pronominal gender systems}

More evidence for the hypothesis comes from partly pronominal gender languages. These are languages whose pronouns have the morphological means to mark a larger array of genders than other agreement targets, notably than determiners and adjectives. The situation is exemplified by Modern Dutch as spoken in the Netherlands (excluding southern and Belgian varieties). Modern Dutch distinguishes two genders, common and neuter, in the attributive domain and on the relative pronouns. The personal pronouns, by contrast, mark three different genders. ${ }^{11}$

\footnotetext{
${ }^{11}$ In my opinion, there are good reasons to claim that Dutch even distinguishes four genders on the pronouns. The common gender demonstrative die is used extensively and can be seen as progressively invading the paradigm of the personal pronouns. This development has precedents in mainland Scandinavian where the former common gender demonstrative den has developed into an ordinary personal pronoun.
} 
(22) Dutch gender agreement

\begin{tabular}{|l|l|l|l|}
\hline $\begin{array}{l}\text { Agreeing } \\
\text { element }\end{array}$ & Attribute & $\begin{array}{l}\text { Relative } \\
\text { pronoun }\end{array}$ & $\begin{array}{l}\text { Personal } \\
\text { pronoun }\end{array}$ \\
\hline Example & $\begin{array}{l}\text { de }[\mathrm{C}] \\
\text { het }[\mathrm{N}]\end{array}$ & $\begin{array}{l}\text { die }[\mathrm{C}] \\
\operatorname{dat}[\mathrm{N}]\end{array}$ & $\begin{array}{l}\text { hij }[\mathrm{M}] \\
\text { zij }[\mathrm{F}] \\
\text { het }[\mathrm{N}]\end{array}$ \\
\hline
\end{tabular}

The present situation is the consequence of syncretism erasing the formal distinctions between masculine and feminine gender on articles, adjectives and relative pronouns. As in English, the personal pronouns were spared in this process. ${ }^{12}$ As a consequence, the distinction between masculine and feminine gender is only marked pronominally. The system now splits into two sorts of genders: masculine and feminine surface as purely pronominal genders, while other targets mark gender with the values common or neuter. Thus, the Dutch gender system combines properties of a traditional, agreement-rich gender system such as in, say, German or Old English, with properties of agreement-poor, pronominal gender systems such as that of Present Day English.

For our purposes, it is interesting to see what happened to the masculine-feminine distinction. Having lost its attributive exponents and being reduced to pronominal marking, it also lost its distributional footing. Without the adnominal evidence, speakers proved unable to maintain the distinction between masculine and feminine nouns. This had the result that the distribution of the two genders was restructured. Masculine and feminine pronouns now no longer mirror the historical syntactic gender of the noun, but are used according to semantic considerations. Feminine pronouns refer to female persons and, occasionally, animals, while masculine pronouns are used for male persons and any sort of animal. Moreover, colloquial Dutch uses masculine pronouns for inanimate objects that are conceptually discrete, bounded or countable (Audring 2006). All other referents can be pronominalized as neuter. Thus, the two exclusively pronominal genders of Dutch are distributed according to a semantic assignment system that distinguishes between male and female human and between count and mass. This distribution shares all the characteristics with the pronominal gender systems discussed above, including alignability to the Individuation Hierarchy. Pronoun usage in spontaneous spoken Dutch can be schematized in the same way as the pronominal gender languages in Table (20) above. $^{13}$

\footnotetext{
12 Indeed, the cross-linguistically typical order of attrition of gender, case and number markers is attribute $>$ predicate $>$ pronoun (Marchese 1988; Priestly 1989; Corbett 1991), with the pronouns often retaining features or feature valures that are no longer marked on other elements.

13 The restriction to "spontaneous spoken" Dutch refers to the fact that such pronoun use is not approved by the standard reference grammars and thus not much used in writing, although it is systematic and widespread in speech (Audring 2006 and forthcoming).
} 
(23) Pronoun usage in spoken Dutch, semantic agreement

\begin{tabular}{|c|c|c|c|c|c|c|c|}
\hline \multirow{3}{*}{ Hierarchy } & male & \multirow{3}{*}{$>$} & \multirow{3}{*}{ animal } & \multirow{3}{*}{$>$} & \multirow{3}{*}{$\begin{array}{l}\text { inanimate } \\
\text { object }\end{array}$} & \multirow{3}{*}{$>$} & \multirow{3}{*}{$\begin{array}{l}\text { mass/ } \\
\text { abstract }\end{array}$} \\
\hline & human & & & & & & \\
\hline & $\begin{array}{l}\text { female } \\
\text { human }\end{array}$ & & & & & & \\
\hline \multirow{2}{*}{ Dutch } & 口 & & \multirow{2}{*}{ a } & & \multirow[t]{2}{*}{ 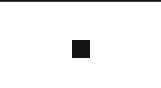 } & & \multirow{2}{*}{$\Delta$} \\
\hline & $\square$ & & & & & & \\
\hline
\end{tabular}

This system exists alongside a syntactic agreement system with the gender values common and neuter. For our purposes, it is relevant to note that the two pronominally marked genders, masculine and feminine, are semantically distributed, and became so as the gender morphology was reduced elsewhere. This confirms the hypothesis that pronominal agreement cannot uphold a system that is not based on semantics.

The same development can be witnessed in the Scandinavian languages. In many varieties of Mainland Scandinavian, the distinction between masculine and feminine on attributives was lost and replaced by a common gender marker (see e.g. Davidson 1990). These languages, represented here by Swedish, show the same sort of mismatch between (ad)nominal and pronominal genders as in Dutch.

(24) Swedish gender agreement

\begin{tabular}{|l|l|l|}
\hline $\begin{array}{l}\text { Agreeing } \\
\text { element }\end{array}$ & Attribute & $\begin{array}{l}\text { Personal } \\
\text { pronoun }\end{array}$ \\
\hline Example & $\begin{array}{l}\operatorname{den}[\mathrm{C}] \\
\operatorname{han}[\mathrm{M}] \\
\operatorname{hon}[\mathrm{F}] \\
\operatorname{det}[\mathrm{C}]\end{array}$ \\
\hline
\end{tabular}

Again, the masculine-feminine-distinction, which used to be pervasive in the whole system, is now reduced to the pronominal domain, making Swedish a partly pronominal gender language. And as in Dutch, this development had an effect on the distribution of the pronouns.

"[When] the masculine and feminine gender had converged into a common gender (realgenus), [...] han/hon (he/she), which were formerly used as grammatical pronouns also for things have now been replaced by den (it)" (Davidson 1990 , p. 152) The orphaned masculine and feminine forms are now used according to semantic rules: han refers to male persons, hon to female persons (see also Holmes and Hinchcliffe 2003). Again, loss of attributive marking has turned the relevant genders from lexico-syntactic to semantics-based.

Both Dutch and Swedish confirm the correlation that was hypothesized on the basis of the cross-linguistic data and supported by the diachronic facts from English. Those genders that rely on pronominal exponence alone are based on semantic 
rules. For Dutch and Swedish, this holds true even though the rest of the gender system is not primarily semantically organized.

\section{Conclusions}

If we want to take the argumentation further, several sorts of evidence invite the same conclusion. Semantic rules are a type of gender assignment rule that can survive and prosper with a minimum of formal exponence. By contrast, formal assignment rules, i.e. phonological and morphological rules, disappear from the system when the markers on attributive agreeing elements are lost. This suggests a fundamental link between gender assignment and gender agreement. Next to the trivial fact that assignment rules have consequences for the agreement that expresses them, there appear to be influences in the other direction: the availability of agreement marking constrains the occurrence of particular organizational principles that we know as gender assignment. Apparently, the three types of gender agreement we saw in (1), phonological, morphological and semantic, differ in their formal requirements. The first two types rarely occur in pronominal gender systems and so can be assumed to require support by more extensive formal marking. Where formal marking is reduced to a single target type, the pronoun, only semantic rules are found.

Note that the correlation is unilateral. Systems with rich agreement can have any sort of assignment system, semantic, formal or a mixture of the two. However, if the agreement is weak, as in pronominal gender systems, we do not seem to find formal assignment systems.

Moreover, there are reasons to believe that weakly marked gender systems need to be supported by conceptual distinctions that are cognitively basic and salient to the human mind. Where formal marking fails, speakers appear to resort to semantic distinctions that are available anyway and can provide a new foundation for the gender system.

For more elaborate systems with more genders and less basic semantic or (partly) form-based assignment rules, more extensive agreement such as attributive and/or predicative marking can be assumed to provide a scaffolding that enables the human mind to reliably pair nouns with their genders.

That formal and semantic gender rules may be different from each other is no novelty. In typological research (primarily Corbett 1991), it has been shown that there is an imbalance between the occurrence of formal (i.e. phonological and/or morphological) and semantic rules in the languages of the world. While logically there are three types of assignment systems, only two of them are found.

(25) Semantic and formal rules in the languages of the world

\begin{tabular}{|l|c|c|}
\hline & Formal rules & No formal rules \\
\hline Semantic rules & $\mathrm{X}$ & $\mathrm{X}$ \\
\hline No semantic rules & - & (no genders) \\
\hline
\end{tabular}


The two types are languages whose gender system is entirely semantically organized and languages with mixed semantic and formal rule systems. The third type, a purely formally organized gender system, is not attested. This suggests that formal and semantic rules have a different status in gender systems and thus in the speakers' minds.

The present work is an attempt to further explore the relation between agreement and assignment in gender systems. With a cross-linguistic survey of pronominal gender languages, it was shown that pronominal gender systems use semantic assignment rules based on basic and general conceptual distinctions. If pronominal gender languages represent an extreme case of an impoverished agreement system, this may suggest that poverty of formal marking correlates with semanticity of assignment rules.

The hypothesis is supported by diachronic data from English. There is historical evidence that loss of agreement morphology triggers a reorganization of the assignment system in semantic terms. The same development can be witnessed in languages where only individual genders are purely pronominal. Again, such genders develop a semantic distribution.

The data invites the hypothesis that gender assignment rules fall into two classes. Formal rules require extensive agreement syntactically close to the noun, while semantic rules can survive even in circumstances where there is a minimum of agreement. Moreover, the evidence adds a new angle to the much-discussed question why most gender systems employ the redundancy of repeated marking. While we cannot explain why agreement arose in the first place, it appears to be functional in the processing or storage of non-semantic assignment systems. Thus, this paper hopes to contribute to the discussion.

Acknowledgements Many thanks to Geert Booij, Gunther de Vogelaer and two anonymous reviewers for their helpful comments.

Open Access This article is distributed under the terms of the Creative Commons Attribution Noncommercial License which permits any noncommercial use, distribution, and reproduction in any medium, provided the original author(s) and source are credited.

\section{References}

Arndt, W. W. (1970). Nonrandom assignment of loanwords: German noun gender. Word, 26, $244-253$. Asher, R. E., \& Kumari, T. C. (1997). Malayalam. London: Routledge.

Audring, J. (2006). Pronominal gender in spoken Dutch. Journal of Germanic Linguistics, 18(2), $85-116$.

Audring, J. (forthcoming). Reinventing pronoun gender. Dissertation VU University Amsterdam.

Austin, P. (1981). A grammar of Diyari, South Australia. Cambridge: Cambridge University Press.

Baerman, M., Brown, D., \& Corbett, G. G. (2005). The syntax-morphology-interface: A study of syncretism. Cambridge: Cambridge University Press.

Barlow, M. (1991). The agreement hierarchy and grammatical theory. In Sutton, L. A., Johnson, C., \& R. Shields (Eds.), Proceedings of the seventeenth annual meeting of the Berkeley Linguistic Society (pp. 30-40). Berkeley: Berkeley Linguistic Society. 
Barlow, M. (1992). A situated theory of agreement. New York, London: Garland Publishing, Inc.

Blake, B. J. (1979). Pitta Pitta. In R. M. W. Dixon., \& B. J. Blake (Eds.), Handbook of Australian languages (Vol. 1, pp. 183-242). Amsterdam: John Benjamins.

Carlson, R. (1993). A sketch of Jo: A Mande language with a feminine pronoun. Mandenkan, 25, 1-109.

Carstensen, B. (1980). The gender of English Loan-Words in German. Studia Anglica Poznaniensa, 12, $3-25$.

Claudi, U. (1985). Zur Entstehung von Genussystemen. Hamburg: Helmut Buske Verlag.

Clyne, M. G. (1969). Inhalt, Klangassoziation und Genus in der deutschen Sprache bei Ein- und Zweisprachigen. Zeitschrift für Phonetik, Sprachwissenschaft und Kommunikation, 22, 218-224.

Corbett, G. G. (1979). The agreement hierarchy. Journal of Linguistics, 15, 203-224.

Corbett, G. G. (1991). Gender. Cambridge: Cambridge University Press.

Corbett, G. G. (2001). Agreement: Terms and boundaries "(The role of agreement in natural language"-Proceedings of the 2001 Texas Linguistic Society conference, Austin, Texas, 2-4 March 2001). Texas. Available under http://uts.cc.utexas.edu/ tls/2001tls/2001proceeds.html

Corbett, G. G. (2005). The canonical approach in typology. In Frajzyngier, Z., Hodges, A., \& D. S. Rood (Eds.), Linguistic diversity and language theories (pp. 25-49). Amsterdam: John Benjamins.

Corbett, G. G. (2006). Agreement. Cambridge: Cambridge University Press.

Corbett, G. G. (2007). Canonical typology, suppletion and possible words. Language, 83, 8-42.

Croft, W. (2001). Radical construction grammar. Oxford: Oxford University Press.

Curzan, A. (2003). Gender Shifts in the History of English. Cambridge: Cambridge University Press.

Davidson, H. (1990). Han hon den. Lund: Lund University Press.

Dekeyser, X. (1980). The diachrony of the gender systems in English and Dutch. In Fisiak, J. (Ed.), Historical morphology (pp. 97-111). The Hague: Mouton.

DeLancey, S. (2003a). Classical Tibetan. In Thurgood, G., \& R. J. LaPolla (Eds.), The Sino-Tibetan Languages (pp. 255-269). London: Routledge.

DeLancey, S. (2003b). Lhasa Tibetan. In Thurgood, G., \& R. J. LaPolla (Eds.), The Sino-Tibetan Languages (pp. 270-288). London: Routledge.

Derbyshire, D. C., \& Payne, D. L. (1990). Noun classification systems of Amazonian languages. In Payne, D. L. (Ed.), Amazonian Linguistics. Studies in Lowland South American Languages (pp. 243-271). Austin: University of Texas Press.

Derbyshire, D. C. (1979). Hixkaryana. Amsterdam: North Holland Publishing.

Dickens, P. J. (2005). In R. Vossen \& Megan Biesele (Eds.) A concise grammar of Ju'hoan. Cologne: Köppe.

Dixon, R. M. W. (1972). The Dyirbal language of North Queensland. Cambridge: Cambridge University Press.

Donaldson, B. C. (1993). A grammar of Afrikaans. Berlin: Mouton de Gruyter.

Donaldson, B. C. (2000). Colloquial Afrikaans. London: Routledge.

Enger, H.-O. (2006). Semantic assignment rules, especially the "crazy" ones. In Amsterdam gender colloquium. Amsterdam, the Netherlands.

Everett, D. L. (1986). Pirahã. In D. C. Derbyshire \& G. Pullum (Eds.), Handbook of Amazonian languages (Vol. I, pp. 200-325). Berlin: Mouton de Gruyter.

Feldman, H. (1986). A grammar of Awtuw. Canberra: Department of Linguistics, Research School of Pacific Studies, the Australian National University.

Gregor, B. (1983). Genuszuordnung. Tübingen: Niemeyer.

Güldemann, T. (2000). Noun categorization in the Non-Khoe lineages of Khoisan. Afrikanische Arbeitspapiere Köln, 63, 5-33.

Haspelmath, M. (1997). Indefinite pronouns. Oxford: Oxford University Press.

Haspelmath, M. (2004). Coordinating constructions: An overview. In M. Haspelmath (Ed.), Coordinating constructions (pp. 3-39). Amsterdam: Benjamins.

Haspelmath, M., Dryer, M. S., Gil, D. \& Comrie, B. (Eds.). (2008). WALS online. Munich: Max Planck Digital Library.

Heringer, H.-J. (1995). Prinzipien der Genuszuweisung. In H. Popp (Ed.), Deutsch als Fremdsprache. An den Quellen eines Faches. Festschrift für Gerhard Helbig zum 65. Geburtstag (pp. 203-216). München: Iudicum.

Holmes, P., \& Hinchcliffe, I. (2003). Swedish: A comprehensive grammar. London: Routledge.

Köpcke, K.-M. (1982). Untersuchungen zum Genussystem der deutschen Gegenwartssprache. Tübingen: Niemeyer.

Köpcke, K.-M., \& Zubin, D. (1984). Sechs Prinzipien für die Genuszuweisung im Deutschen: Ein Beitrag zur natürlichen Klassifikation, Linguistische Berichte, 93, 26-51. 
Jenewari, C. E. W. (1983). Defaka, Ijo's closest linguistic relative. In I. R. Dihoff (Ed.), Current approaches to African linguistics (pp. 85-111). Dordrecht: Foris.

Jensen, C. (1999). Tupí-Guaraní.” In R. M. W. Dixon \& A. Y. Aikhenvald (Eds.), The Amazonian languages (pp. 125-63). Cambridge: Cambridge University Press.

Lang, A. (1976). The semantic base of gender in German. Lingua, 40, 55-68.

Levine, G. S. (1999). Gender assignment to German nonsense nouns: What does the native speaker know that the non-native speaker doesn't? In A. Greenhill (Ed.), Proceedings from BUCLD 23 (pp. 397406). Boston: Cascadilla.

Macaulay, M. (1996). A grammar of Chalcatongo Mixtec. Berkeley: University of California Press.

Mace, J. (2003). Persian grammar. London: Routledge.

Marchese, L. (1988). Noun classes and agreement systems in Kru: A historical approach. In M. Barlow \& C. A. Ferguson (Eds.), Agreement in natural languages: Approaches, theory, descriptions, (pp. 323-341). Stanford, CA: CSLI.

McLendon, S. (1975). A grammar of eastern Pomo. Berkeley: University of California Press.

Mithun, M. (1990). Third-person reference and the function of pronouns in Central Pomo natural speech. International Journal of American Linguistics, 56(3), 361-376.

Moore, S. (1921). Grammatical and natural gender in Middle English. PMLA, 36, 79-103.

Moshinsky, J. (1974). A grammar of southeastern Pomo. Berkeley: University of California Publications.

Payne, J. R. (1989). Pamir languages. In R. Schmitt (Ed.), Compendium Linguarum Iranicarum (pp. 417-444). Wiesbaden: Reichert.

Phillips, J. D. (2004). Manx. München: Lincom Europa.

Ponelis, F. (1979). Afrikaanse sintaksis. Pretoria: van Schaik.

Premsrirat, S. (1987). Khmu, a minority language of Thailand. Canberra: Australian National University.

Priestly, T. M. S. (1983). On 'Drift' in Indo-European gender systems. Journal of Indo-European Studies, 11(3-4), 339-363.

Quirk, R., Greenbaum, S., Leech, G., \& Svartvik, J. (1985). A comprehensive grammar of the English language. London: Longman.

Rickard, D. T. (1970). Kru grammar: A preliminary study. Monrovia: Department of Literacy Work and Literature Production of the United Methodist Church.

Salmons, J. (1993). The structure of the Lexicon: Evidence from German gender assignment. Studies in Language, 17(2), 411-435.

Salmons, J. (1994). Sketch of an interlanguage rule system: Advances non-native German gender assignment. In C. Blackshire-Belay (Ed.), Current issues in second language acquisition (pp. 187-201). Lanham, NY, London: University Press of America.

Sasse, H.-J. (1993). Syntactic categories and subcategories. In J. Jacobs, A. von Stechow, W. Sternefeld, \& T. Vennemann (Eds.), Syntax. Ein internationales Handbuch zeitgenössischer Forschung/An International Handbook of Contemporary Research (Vol. 1, pp. 646-686). Berlin: de Gruyter.

Schlick, W. (1984). Die Kriterien für die deutsche Genuszuweisung bei substantivischen Anglizismen. German Quarterly, 57(3), 402-431.

Siemund, P. (2008). Pronominal gender in English-A study of English varieties from a cross-linguistic perspective. London: Routledge.

Siewierska, A. (2004). Person. Cambridge: Cambridge University Press.

Tucker, G. R., Lambert, W. E., \& Rigault, A. A. (1977). The French speaker's skill with grammatical gender: An example of rule-governed behavior. Den Haag: Mouton

Wiesemann, U. (1986). Pronominal systems. Tübingen: Narr.

Williamson, K. (1965). A grammar of the Kolokuma dialect of Ijo. Cambridge: Cambridge. University Press.

Williamson, K., \& Blench, R. (2000). Niger-Congo. In B. Heine, \& D. Nurse (Eds.), African languages: An introduction (pp. 11-42), Cambridge: Cambridge University Press.

Zaliznjak, A. A. (1973). O ponimanii termina 'padež' v lingvističeskix opisanijax. In A. A. Zaliznjak (Ed.), Problemy grammatičeskogo modelirovanija (pp. 53-87). Moscow: Nauka. (Reprinted in. Russkoe imennoe slovoizmenenie: s priloženiem izbrannyx rabot po sovremennomu russkomu jazyku i obščemu jazykoznaiju (pp. 613-647) A. A. Zaliznjak, 2002, Moscow: Jazyki slavjanskoj kultury. 